HEAD AND NECK

\title{
Supraclavicular artery fascial flap (SAFF): a valuable tool in salvage total laryngectomy and hemipharyngolaryngectomy
}

\author{
Lembo peduncolato di fascia sovraclaveare: utile strumento nella laringectomia \\ ed emifaringolaringectomia totale di salvataggio
}

\author{
Francesco Mattioli', Matteo Fermi ${ }^{1,2,3}$, Andrea Martone', Michael Ghirelli', Leone Giordano ${ }^{4}$, Davide Di Santo ${ }^{3}$, \\ Mario Bussi ${ }^{4}$, Livio Presutti $1,2,3$ \\ ${ }^{1}$ Department of Otorhinolaryngology Head and Neck Surgery, University Hospital of Modena, Modena, Italy; ${ }^{2}$ Department of \\ Otorhinolaryngology Head and Neck Surgery, IRCCS Azienda Ospedaliero-Universitaria di Bologna, Policlinico S. Orsola-Malpighi, \\ Bologna, Italy; ${ }^{3}$ Department of Specialist, Diagnostic and Experimental Medicine (DIMES), Alma Mater Studiorum, Università di \\ Bologna, Bologna, Italy; ${ }^{4}$ Department of Otorhinolaryngology, San Raffaele Scientific Institute, Milan, Italy
}

\section{SUMMARY}

Objective. To describe the surgical technique of the supraclavicular artery fascial flap (SAFF) and outcomes in neopharyngeal covering with overlay technique during salvage total laryngectomy for residual or recurrent carcinoma after chemo/radiation treatment. Methods. Chart review of patients treated between October 2018 and February 2019 at two tertiary care hospitals. Variables extracted from patient records were age, gender, history of chemo/radiation therapy, neck dissection, surgical and postoperative complications. Outcomes measured were surgical time, postoperative complications and flap failure, oral intake start and patient discharge.

Results. Ten male patients were included. Median age was 64 years. All patients underwent salvage total laryngectomy and neopharyngeal covering with SAFF. Mean flap harvest time was 25 minutes. No surgical complications or flap failure were recorded. Oral intake was started on a median of post-operative day 10 . No cases of pharyngocutaneous fistula were encountered. Conclusions. SAFF is a reliable, easy and quick to harvest flap, which provides a good alternative to other pedicled and free flaps for hypopharyngeal coverage in laryngeal salvage surgery. Donor site morbidity is almost null and postoperative complications are very rare.

KEY WORDS: salvage laryngectomy, chemoradiation, pedicled flap, pharyngocutaneous fistula, supraclavicular artery

\section{RIASSUNTO}

Scopo dello studio. Descrivere la tecnica chirurgica del lembo SAFF e le sue applicazioni e risultati nella ricostruzione faringea durante laringectomia di salvataggio per SCC persistenti dopo trattamento chemio/radioterapico.

Metodi. Analisi retrospettiva di pazienti trattati fra 10/2018 e 02/2019 in due centri ospedalieri di terzo livello. Le variabili analizzate sono età, sesso, precedente chemio/radioterapia, svuotamento laterocervicale, complicanze intra e post-operatorie. I risultati valutati sono tempo chirurgico, complicanze post-operatorie, fallimento del lembo, tempo d'inizio dell'alimentazione per os e durata della degenza.

Risultati. Sono stati inclusi 10 pazienti maschi. L'età mediana era 64 anni. Il tempo mediano di allestimento del lembo è stato di 25 minuti. Non sono state registrate complicanze intra o post-operatorie. L'inizio mediano dell'alimentazione per os è stato in decima giornata post-operatoria. Non sono stati osservati casi di fistolizzazione faringo-cutanea.

Conclusioni. Il SAFF è un lembo affidabile, facile e rapido da allestire, che offre una valida alternativa ad altri lembi peduncolati e liberi per la copertura ipofaringea nella chirurgia laringea di salvataggio. La morbilità del sito donatore è praticamente nulla e le complicanze post-operatorie sono molto rare.

PAROLE CHIAVE: laringectomia di salvataggio, chemioradioterapia, lembi peduncolati, fistola faringocutanea, arteria sovraclaveare
Received: October 1, 2020

Accepted: June 26, 2021

Published online: November 26, 2021

Correspondence

Andrea Martone

Department of Otorhinolaryngology, Head \& Neck

Surgery, University Hospital of Modena, Italy

Tel. +390594 222402. Fax +390594222454

E mail: andreamartone@gmail.com

Funding

None.

Conflict of interest

The Authors declare no conflict of interest.

How to cite this article: Mattioli F, Fermi M, Martone A, et al. Supraclavicular artery fascial flap (SAFF): a valuable tool in salvage total laryngectomy and hemipharyngolaryngectomy. Acta Otorhinolaryngol Ital 2021;41:523-529. https:// doi.org/10.14639/0392-100X-N1152

๑ Società Italiana di Otorinolaringoiatria e Chirurgia Cervico-Facciale

\section{(c) (1) () $)$}

This is an open access article distributed in accordance with the CC-BY-NC-ND (Creative Commons Attribution-NonCommercial-NoDerivatives 4.0 International) license. The article can be used by giving appropriate credit and mentioning the license, but only for non-commercial purposes and only in the original version. For further information: https:// creativecommons.org/licenses/by-nc-nd/4.0/deed.en 


\section{Introduction}

Most laryngectomies are performed in the salvage setting due to organ preservation protocols with concurrent chemoradiation (CRT) ${ }^{1}$. Radiation and chemoradiation are known for their adverse effects on soft tissue which leads to a significantly higher risk of postoperative complications, especially pharyngocutaneous fistula (PCF). This adverse outcome remains of significant concern and has become the focus of reconstructive surgeons. The main goal is to transfer healthy vascularised tissue from outside the radiation field, thus enhancing the healing process and reducing the incidence of wound complications. The choices of donor tissues are usually among pedicled or microvascular free flaps. Moreover, surgeons have adopted two different techniques when using vascularised tissue following salvage total laryngectomy (STL): vascularised tissue to increase the pharyngeal circumference by a patch graft and vascularised tissue to reinforce the pharyngeal repair ${ }^{2}$.

Herein, we describe a new reconstructive option in neopharyngeal covering during STL based on supraclavicular vessels: the supraclavicular artery fascial flap (SAFF).

\section{Methods}

A descriptive retrospective study was conducted on patients subjected to STL and SAFF reconstruction after radiation or CRT between October 2018 and February 2019 at two tertiary care hospitals. Patient eligibility criteria for SAFF reconstruction were laryngeal cancer, with or without extension to pyriform sinus, after previous radiation or CRT. Exclusion criteria were cancer involving the posterior hypopharyngeal wall or both pyriform sinuses. All patients underwent a pre-operative Doppler evaluation to demonstrate the presence of the vascular pedicle.

Variables extracted from patient records were age, gender, history of chemoradiation or radiation therapy prior to SAFF reconstruction, neck dissection prior or during reconstructive surgery, surgical and postoperative complications. Adverse events were defined as any deviation from normal postoperative course. Descriptive statistical analysis was conducted with IBM SPSS Statistics Version 19.0 (IBM Corp, Armonk, NY, USA). Results are presented as median (range) for continuous variables and as frequencies for categorical variables. Ethics committee approval: University Hospital of Modena and San Raffaele Scientific Institute's ethics committees do not require approval for anonymised retrospective chart reviews.

\section{Surgical technique}

The supraclavicular artery usually has a diameter of 1-1.5 $\mathrm{mm}$ and travels for $30 \mathrm{~mm}$ perpendicularly from the trans- verse cervical artery before piercing the deep fascia of the deltoid muscle. The supraclavicular artery can be identified in a triangular area bounded inferiorly by the clavicle, medially by the posterior border of the sternocleidomastoid muscle and laterally by the external jugular vein. These anatomical landmarks can be marked pre-operatively (Fig. 1). A rectilinear incision including skin and subcutaneous tissue is made from the point of origin of the vascular pedicle to $1 \mathrm{~cm}$ lateral to the acromion. Alternatively, the classic shape of the fascio-cutaneous flap is drawn and only the anterior portion is incised (Fig. 2).

The incision can also be made along the main axis of the flap to elevate two shorter flaps (superior and inferior), thus reducing the risk of distal loss in case of wide flaps.

The fascial plane is identified distally at the level of the deltoid muscle. Once this plane has been highlighted, it is exposed anteriorly and posteriorly to cover the entire length of the flap. It is useful to maintain a layer of subcutaneous adipose tissue above the fascial plane.

The flap is dissected in a distal-to-proximal manner along a subfascial plane over the deltoid muscle. The fascia of the deltoid muscle is incised and detached according to the classical form of the supraclavicular flap. Normally, a 6-7

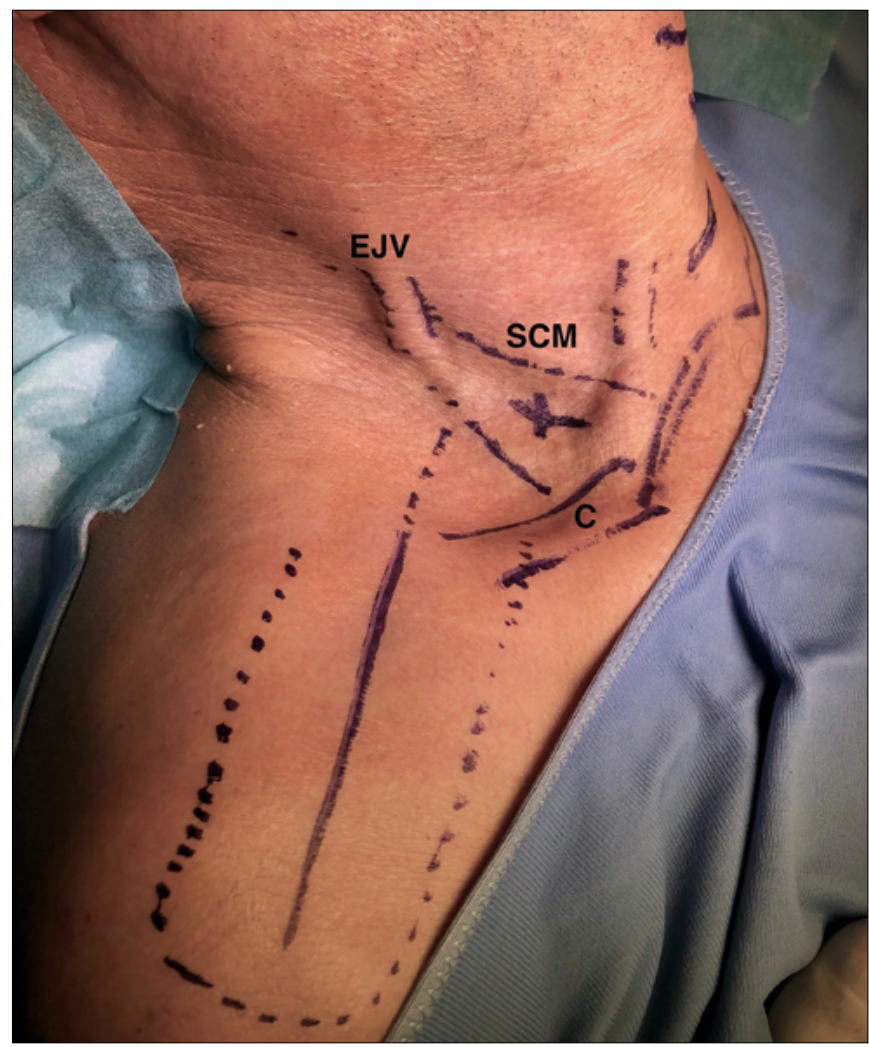

Figure 1. Surgical landmarks. SCM: sternocleidomastoid muscle; C: clavicle; EGV: external jugular vein. 


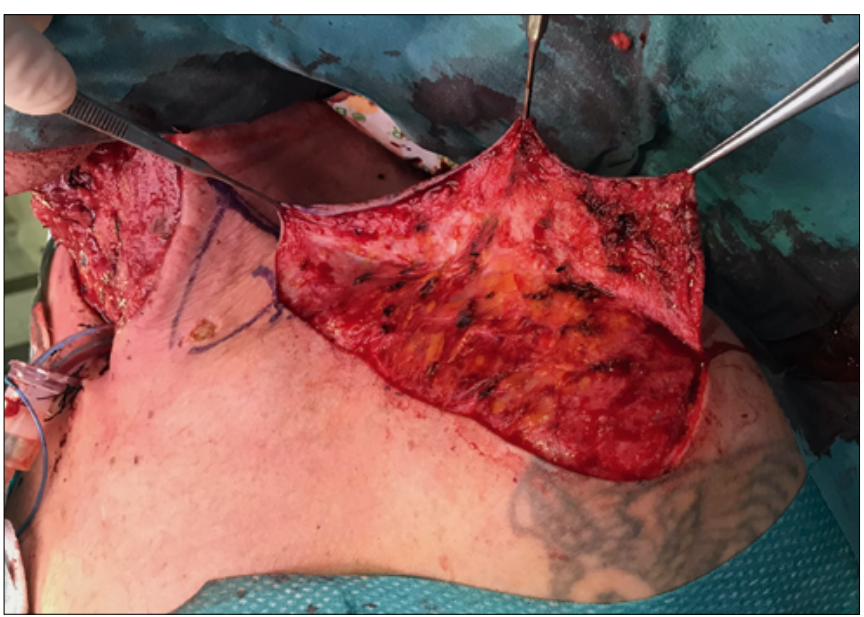

Figure 2. Skin and subcutaneous tissue incision.

$\mathrm{cm}$ (antero-posterior) by $20-26 \mathrm{~cm}$ (lateromedial) flap is obtained. The flap's length usually allows for neopharyngeal coverage without further need to skeletonise the vascular axis, thus avoiding its accidental injury. A subfascial plane must be followed while elevating the flap, except for the clavicular region where a subperiosteal plane must be followed (Fig. 3).

Once the pedicle is isolated, the flap is rotated over the pharyngeal reconstruction (Fig. 4).

An incision of the anterior portion of the SCM muscle can be performed to facilitate the positioning of the flap. Otherwise, the flap can be placed under the muscle after identification and preservation of the spinal nerve. Final steps consist in placing a suction drain and suturing the skin with non-absorbable separate threads.

\section{Results}

Ten male patients were included in the present study. Median age was 64 years (range 54-82). All patients underwent salvage total laryngectomy and neopharyngeal covering with SAFF. Eight patients underwent salvage total laryngectomy, and two were subjected to salvage total hemipharyngolaryngectomy (Tab. I). Four were staged as T3NO according to TNM Classification of Malignant Tumors, Eight Edition ${ }^{3}$. EZ and CA were selected T3N0 amenable to larynx preserving surgery, thus performed only RT and not CRT. FP could not undergo CT for vascular and renal co-pathologies, while FC was not deemed fit due to age. MF and GM were subjected to prior surgical treatment (OPHL IIa and type IV cordectomy respectively) that resulted in R1 margins, after which they underwent adjuvant therapy (RT and CRT). Salvage total laryngectomy was performed

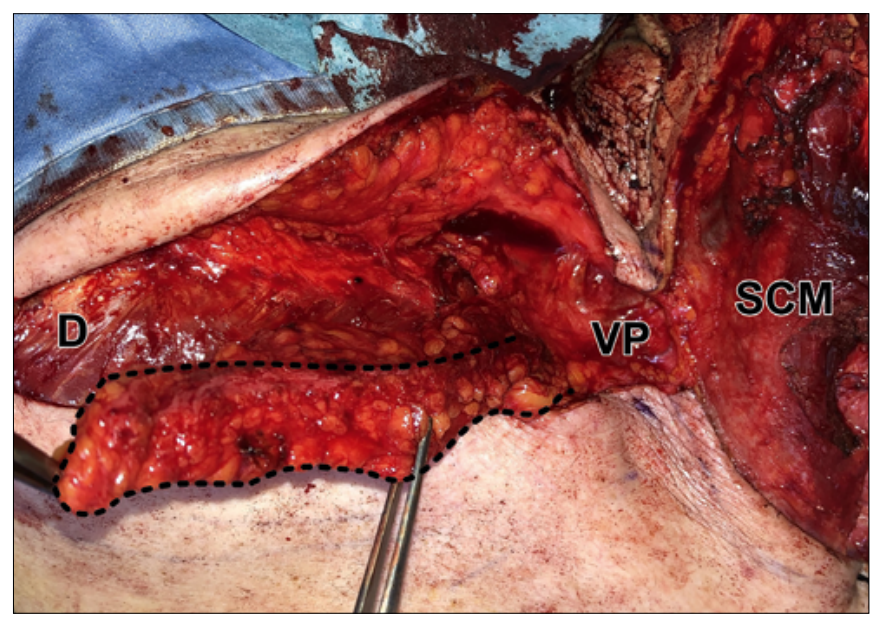

Figure 3. Right supraclavicular artery fascial flap isolation and elevation. Dotted line highlights the SAFF. D, deltoid muscle. VP, vascular pedicle. SCM, sternocleidomastoid muscle.

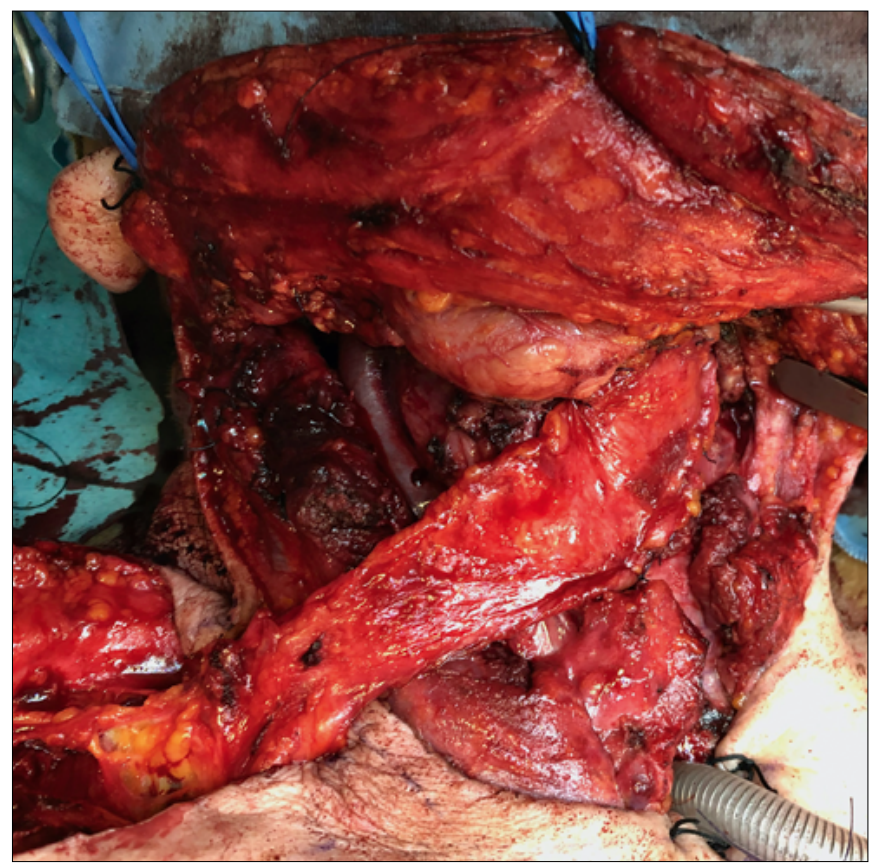

Figure 4. Positioning of the SAFF over the pharyngeal reconstruction.

on GM because of a second primary posterior commissure cancer 120 months after radiation therapy. STL was performed on MF because of disease recurrence 16 months after the end of RT.

Mean flap harvest time was 25 minutes (range 23-28). Bilateral selective neck dissection (SND) was performed in five patients $(50 \%)$, ipsilateral SND in one patient $(10 \%)$ and no neck dissection was performed in two patients $(20 \%)$. 
Table I. Patient characteristics, oncological history and treatment (continues on page 527).

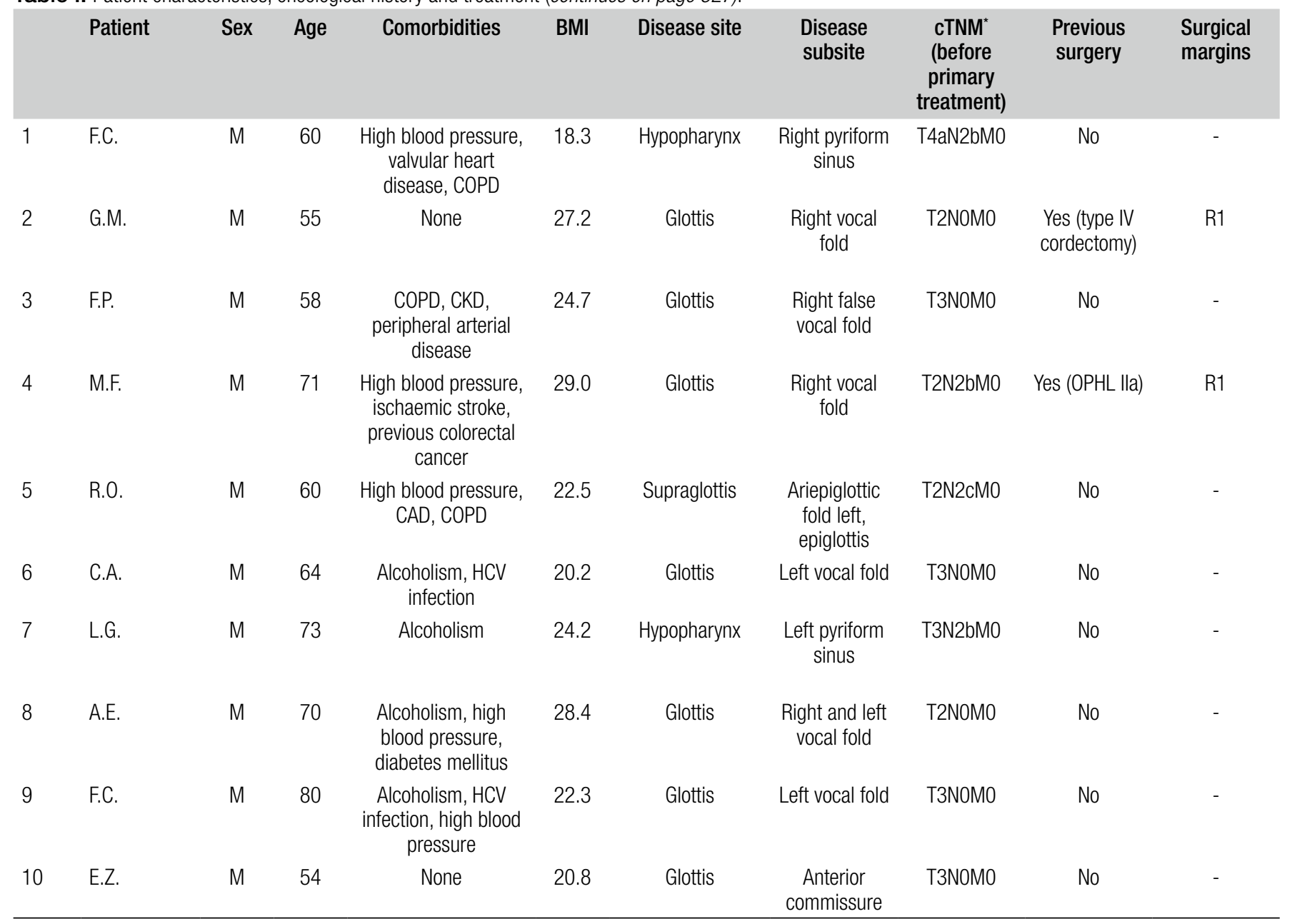

${ }^{*}$ TNM Eighth Edition ${ }^{3 ;}$ pyr: pyriform sinus.

No surgical complications nor flap failure were recorded. Patients received enteral feeding through a nasogastric tube. None of the patients underwent percutaneous endoscopic gastrostomy placement. Oral feeding was delayed until a negative salivary fistula blue dye test, which was performed in median post-operative day 9 (range 8-10). No cases of PCF were encountered. Patients were dismissed in median post-operative day 14 (range 13-15). No postoperative complications were recorded.

\section{Discussion}

Pharyngocutaneous fistula (PCF) has been a challenge for head and neck surgeons for the treatment of advanced pharyngolaryngeal cancer ${ }^{1}$. PCFs extend hospitalisation time due to increased necessity of wound care, and may lead to major vascular injuries such as carotid or jugular vein rupture. PCFs may also require revision surgery which further delays return to oral feeding and vocal rehabilitation. Several authors have reported 15\%-30\% rates of PCF for patients undergoing salvage total laryngectomy (STL) after radiation or CRT with an approximate 2.28 -fold increased risk ${ }^{2}$. CRT damage to surrounding tissue translates in an increased risk of complications within the first year after treatment ${ }^{4}$. Hence, different surgical techniques have been developed to reduce PCFs 5 .

Surgeons have adopted two different techniques when using vascularised tissue following STL: vascularised tissue to augment pharyngeal circumference by a patch graft and vascularised tissue to reinforce pharyngeal repair. Pectoralis major myofascial flap (PMMF) and pectoralis major myocutaneous flap (PMMC) have been the most commonly used pedicled flaps for this purpose ${ }^{2}$. However, the bulky nature of the pectoralis major muscle may prevent closure of the overlying skin and the morbidity of the donor site is significant, especially for female patients where incisions 
Table I. Patient characteristics, oncological history and treatment (follows from page 526).

\begin{tabular}{|c|c|c|c|c|c|c|c|c|c|c|}
\hline & Patient & $\begin{array}{l}\text { Previous } \\
\text { RT }\end{array}$ & $\begin{array}{l}\text { RT Dose } \\
\text { (Gy) }\end{array}$ & $\begin{array}{l}\text { Previous } \\
\text { CT }\end{array}$ & $\begin{array}{c}\text { Reason for } \\
\text { salvage treatment }\end{array}$ & $\begin{array}{l}\text { Time to } \\
\text { relapse } \\
\text { (months) }\end{array}$ & Treatment & $\begin{array}{c}\text { Neck } \\
\text { dissection }\end{array}$ & урTNM* & $\begin{array}{l}\text { Present } \\
\text { status }\end{array}$ \\
\hline 1 & F.C. & Yes & 66 & Yes & Recurrence & 9 & $\begin{array}{c}\text { Salvage total } \\
\text { laryngectomy } \\
\text { + right pyr" }\end{array}$ & $\begin{array}{l}\text { Right II-IV } \\
\text { SND }\end{array}$ & T4aNOMO & NED \\
\hline 2 & G.M. & Yes & 66 & No & $\begin{array}{l}\text { Second primary } \\
\text { T (posterior } \\
\text { commissure) }\end{array}$ & 120 & $\begin{array}{l}\text { Salvage total } \\
\text { laryngectomy }\end{array}$ & $\begin{array}{l}\text { Bilateral II-IV } \\
\text { SND }\end{array}$ & T2NOMO & NED \\
\hline 3 & F.P. & Yes & 64 & No & Recurrence & 21 & $\begin{array}{l}\text { Salvage total } \\
\text { laryngectomy }\end{array}$ & $\begin{array}{l}\text { Bilateral II-IV } \\
\text { SND }\end{array}$ & T3N2bM0 & NED \\
\hline 4 & M.F. & Yes & 60 & Yes & Recurrence & 16 & $\begin{array}{l}\text { Salvage total } \\
\text { laryngectomy }\end{array}$ & $\begin{array}{l}\text { Bilateral IIIIV } \\
\text { SND }\end{array}$ & T4aN2bM0 & $\begin{array}{l}\text { NED on primary } \\
\text { T. In treatment for } \\
\text { primary prostate } \\
\text { cancer }\end{array}$ \\
\hline 5 & R.O. & Yes & 64 & Yes & Recurrence & 14 & $\begin{array}{l}\text { Salvage total } \\
\text { laryngectomy }\end{array}$ & $\begin{array}{l}\text { Bilateral II-V } \\
\text { SND }\end{array}$ & T3N2bM0 & NED \\
\hline 6 & C.A. & Yes & 60 & No & Recurrence & 28 & $\begin{array}{l}\text { Salvage total } \\
\text { laryngectomy }\end{array}$ & $\begin{array}{l}\text { Bilateral II-IV } \\
\text { SND }\end{array}$ & T3N2cM0 & NED \\
\hline 7 & L.G. & Yes & 70 & Yes & Recurrence & 12 & $\begin{array}{l}\text { Salvage total } \\
\text { laryngectomy } \\
+ \text { left pyr }\end{array}$ & $\begin{array}{l}\text { Bilateral II-IV } \\
\text { SND }\end{array}$ & T4aN2bM0 & NED \\
\hline 8 & A.E. & Yes & 66 & No & Recurrence & 15 & $\begin{array}{l}\text { Salvage total } \\
\text { laryngectomy }\end{array}$ & $\begin{array}{l}\text { Bilateral II-V } \\
\text { SND }\end{array}$ & T3NOMO & NED \\
\hline 9 & F.C. & Yes & 66 & No & Recurrence & 13 & $\begin{array}{l}\text { Salvage total } \\
\text { laryngectomy }\end{array}$ & $\begin{array}{l}\text { Bilateral II-V } \\
\text { SND }\end{array}$ & T3N2aM0 & NED \\
\hline 10 & E.Z. & Yes & 66 & No & Recurrence & 14 & $\begin{array}{l}\text { Salvage total } \\
\text { laryngectomy }\end{array}$ & $\begin{array}{l}\text { Bilateral II-IV } \\
\text { SND }\end{array}$ & T3N2aMO & NED \\
\hline
\end{tabular}

*TNM Eighth Edition ${ }^{3 ;}$ pyr: pyriform sinus.

encompass the mammary region. Additionally, shoulder dysfunction, difficulties with vocal rehabilitation and decreased chest wall compliance have been reported ${ }^{6}$. Several authors use pedicled flaps as a second-line option when free flap reconstruction is not feasible ${ }^{7}$. The radial forearm free flap (RFFF), the anterolateral thigh flap (ALTF) and the temporoparietal fascia free flap (TPFF) are the most used in STL reconstructive setting. The ALTF is virtually free from donor site morbidity, but its added bulk might be troublesome for optimal reconstruction. Nonetheless, free flaps are characterized by increased operative times, extensive postoperative monitoring and microvascular surgery expertise $^{8}$.

Moreover, in the reconstruction of head and neck cancer patients who have undergone previous neck dissections or radiotherapy, the paucity of good calibre and quality vessels for microvascular anastomosis constitute a real challenge for microvascular surgeons.
A growing interest in the use of tissue harvested from the cervicohumeral area has been reported recently ${ }^{9-12}$. Su et al. showed several advantages from using the SCAIF over distant free flaps in head and neck reconstruction ${ }^{13}$, especially after RT or revision surgery. Granzow and coworkers compared the SCAIF with the RFFF concluding that the former should be considered a first-choice reconstructive option for head and neck defects ${ }^{8}$. The main disadvantage of this flap is the size of the skin paddle, limited by the need for primary closure, and a shorter vascular pedicle. Furthermore, several authors advise against the use of this flap in cases of ipsilateral neck metastasis and following neck radiation ${ }^{14}$.

Herein, we describe a novel and valuable reconstructive technique based on supraclavicular vessels: the supraclavicular artery fascial flap (SAFF). The fascia of the deltoid region can provide thin, pliable and vascularised tissue that can help in resurfacing reconstructions in the head and neck dis- 
trict ${ }^{15}$. Complications to the donor site are not frequent, as the shoulder and supraclavicular fossa skin is left in place. In fact, no wound complications were reported in present case series. Based on our results a good aesthetic outcome of the donor site can be achieved after SAFF reconstruction (Fig. 5). Several patients reported tightness in the shoulder and minor widening of the donor-site scar was common. Wound dehiscence and widened scarring are more frequent when tension at closure site increases, especially in patients with comorbidities and following CRT or radiation therapy. Care should be taken, especially while suturing the skin overlying the acromion in order to avoid excessive tension which might hinder optimal healing as it is the point of maximal movement ${ }^{16}$. There is no need for pedicle section since the flap is positioned in the subcutaneous tissue. Thus, second stage surgery can be avoided.

In our opinion, SAFF represents an effective and safe option to prevent postoperative fistula in patients who undergo STL after CRT or radiation for laryngeal cancer. In our experience, SAFF reconstruction is a valuable option when pharyngeal resurfacing is required to prevent PCF. It can be easily and rapidly harvested to reinforce pharyngeal suture line, providing healthy and vascularised tissue to a critical surgical area without compromising primary closure of the donor site. This is especially of use in patients with previous radiation treatment or in case of free flap contraindication, where pedicled flaps can become a first-choice treatment ${ }^{8}$. This pilot multiinstitutional experience with SAFF in STL setting has demonstrated its safety and low complication rates. Even though the number of patients is limited, no complications were encountered. For these reasons, we deem the results encouraging for patients who must undergo STL after neck irradiation. The main contraindications to SAFF are previous neck dissection with absence of transverse cervical vessel, previous shoulder surgery and skin cancer of the deltoid region. Preoperative doppler evaluation is recommended to verify the reliability of the transverse cervical pedicle before harvesting this flap, especially in previously operated patients. Although our experience with SAFF is still relatively limited, it is the first reported experience to date. Over time we expect to confirm these results and compare them with free flaps and other pedicled flaps in the setting of STL.

\section{Conclusions}

SAFF is a reliable, easy and quick to harvest flap, which provides a good alternative to other pedicled and free flaps for laryngeal salvage surgery. Donor site morbidity is almost null and postoperative complications are very rare. The possibility to obtain a wide flap without compromising primary closure of the donor site and the relative absence of risk

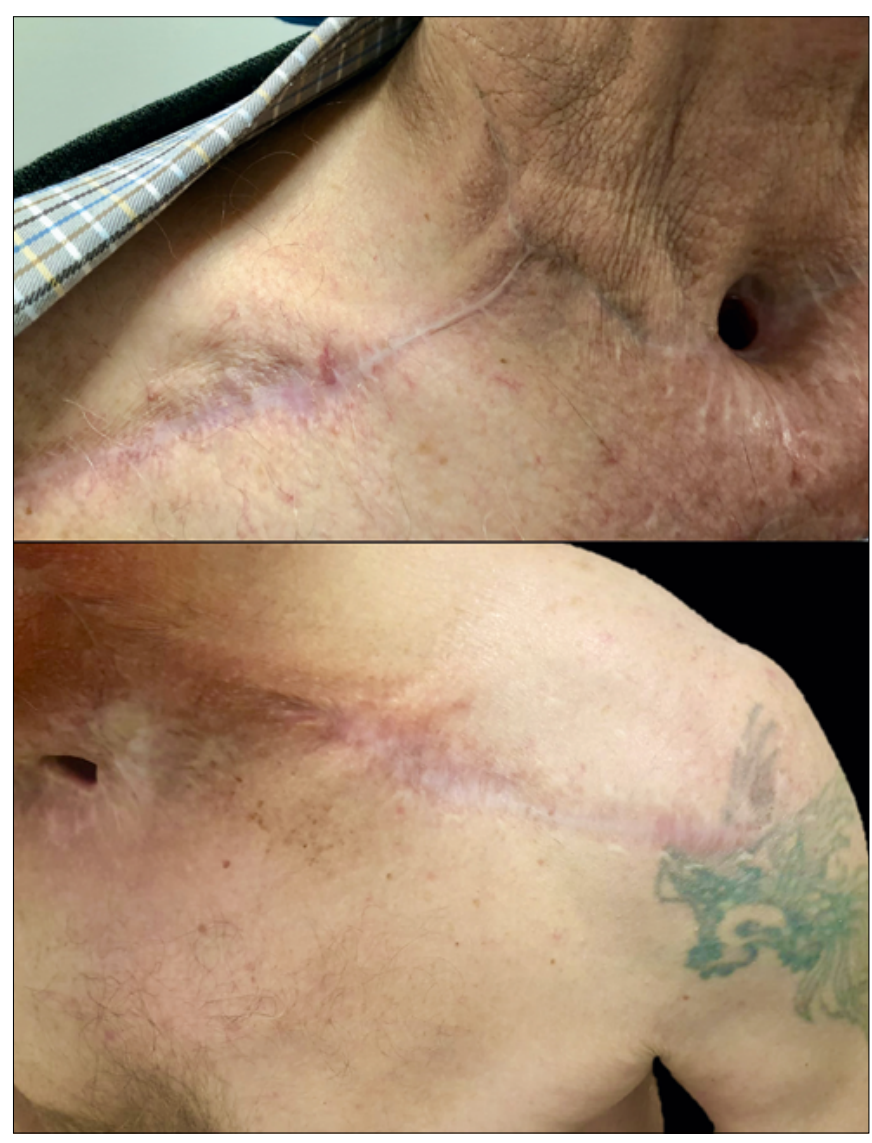

Figure 5. Aesthetic outcome 1 month after surgery.

of complications make the SAFF a valuable option when pharyngeal resurfacing is required to prevent PCF. This flap might gain popularity over the coming years, becoming a strong point for head and neck reconstructive surgeons.

\section{References}

1 Forastiere AA, Goepfert H, Maor M, et al. Concurrent chemotherapy and radiotherapy for organ preservation in advanced laryngeal cancer. N Engl J Med 2003;349:2091-2098. https://doi.org/10.1056/ NEJMoa031317

2 Paleri V, Drinnan M, van den Brekel MWM, et al. Vascularized tissue to reduce fistula following salvage total laryngectomy: a systematic review. Laryngoscope 2014;124:1848-1853. https://doi.org/10.1002/ lary. 24619

3 Brierley J, Gospodarowicz MK, Wittekind CH, editors. TNM classification of malignant tumours. Eighth edition. Oxford, UK, Hoboken, NJ: John Wiley \& Sons Inc.; 2017.

4 Sassler AM, Esclamado RM, Wolf GT. Surgery after organ preservation therapy. Analysis of wound complications. Arch Otolaryngol Head Neck Surg 1995;121:162-165. https://doi.org/10.1001/ archotol.1995.01890020024006

5 Fung K, Teknos TN, Vandenberg CD, et al. Prevention of wound complications following salvage laryngectomy using free vascularized tissue. Head Neck 2007;29:425-430. https://doi.org/10.1002/hed.20492 
6 Higgins KM, Ashford B, Erovic BM, et al. Temporoparietal fascia free flap for pharyngeal coverage after salvage total laryngectomy. Laryngoscope 2012;122:523-527. https://doi.org/10.1002/lary.22477

7 Molteni G, Sacchetto A, Sacchetto L, et al. Optimal management of post-laryngectomy pharyngo-cutaneous fistula. Open Access Surgery 2020;13:11-25. https://doi.org/10.2147/OAS.S198038

8 Granzow JW, Suliman A, Roostaeian J, et al. Supraclavicular artery island flap (SCAIF) vs free fasciocutaneous flaps for head and neck reconstruction. Otolaryngol Head Neck Surg 2013;148:941-948. https://doi.org/10.1177/0194599813476670

9 Giordano L, Santo DD, Bondi S, et al. The supraclavicular artery island flap (SCAIF) in head and neck reconstruction: an Italian multiistitutional experience. Acta Otorhinolaryngol Ital 2018;38:497-503. https://doi.org/10.14639/0392-100X-1794

10 Giordano L, Di Santo D, Occhini A, et al. Supraclavicular artery island flap (SCAIF): a rising opportunity for head and neck reconstruction. Eur Arch Otorhinolaryngol 2016;273:4403-4412. https://doi. org/10.1007/s00405-016-4092-4

11 Spiegel JL, Pilavakis Y, Weiss BG, et al. Quality of life in patients after reconstruction with the supraclavicular artery island flap (SCAIF) versus the radial free forearm flap (RFFF). Eur Arch Otorhinolaryngol 2019;276:2311-2318. https://doi.org/10.1007/s00405-019-05478-6
12 Emerick KS, Herr MA, Deschler DG. Supraclavicular flap reconstruction following total laryngectomy: supraclavicular flap laryngectomy defects. Laryngoscope 2014;124:1777-1782. https://doi.org/10.1002/ lary. 24530

13 Su T, Pirgousis P, Fernandes R. Versatility of supraclavicular artery island flap in head and neck reconstruction of vessel-depleted and difficult necks. J Oral Maxillofac Surg 2013;71:622-627. https://doi. org/10.1016/j.joms.2012.07.005

14 Cordova A, Pirrello R, D'Arpa S, et al. Vascular anatomy of the supraclavicular area revisited: feasibility of the free supraclavicular perforator flap. last Reconstr Surg 2008;122:1399-1409. https://doi. org/10.1097/PRS.0b013e3181891651

15 Wang Z, Sano K, Inokuchi T, et al. The free deltoid flap: microscopic anatomy studies and clinical application to oral cavity reconstruction. Plast Reconstr Surg 2003;112:404-411. https://doi.org/10.1097/01. PRS.0000070725.74647.1E

16 Kokot N, Mazhar K, Reder LS, et al. The supraclavicular artery island flap in head and neck reconstruction: applications and limitations. JAMA Otolaryngol Head Neck Surg 2013;139:1247. https:// doi.org/10.1001/jamaoto.2013.5057 